\title{
Helicobacter pylori as an Etiologic Factor in Primary Lung Carcinoma
}

\author{
Primer Akciğer Kanserinde Etyolojik Faktör Olarak Helicobacter Pylori
}

Nur BÜYÜKPINARBAŞILI iD

Department of Pathology, Bezmialem Vakif University School of Medicine, İstanbul, Turkey

\section{ABSTRACT}

Objective: Although the importance of environmental and occupational exposure to carcinogenic agents in pulmonary carcinoma is well known, some other factors, such as familial predisposition, genetic abnormalities, and recently, the presence of Helicobacter pylori infection, are being disputed. This study focused on the relationship between pulmonary carcinoma and $H$. pylori infection.

Methods: In total, 48 histologically verified and operated patients with pulmonary carcinoma, including 38 males and 10 females, were included; 22 of the cases were of squamous cell carcinomas and 26 were adenocarcinomas. The control group composed of 20 patients who underwent pulmonary operation for causes other than lung cancer. Adjacent non-neoplastic parenchymal and bronchial tissue examples were stained using the $\mathrm{Gi}$ emsa stain in carcinoma cases. The pulmonary tissue-contained bronchial sections were stained in control cases. The bronchial epithelia and lumina in the Giemsa stained slides were examined for $H$. pylori bacilli.

Results: H. pylori was found in 2 of 48 carcinoma cases. The histopathological diagnosis of these 2 cases was squamous cell carcinoma. But there wasn't any case stained for H.pylori in the control group.

Conclusion: The relationship between pulmonary carcinoma and $H$. pylori infection had been researched through serological studies; however, conflicting evidences have been obtained. The bacterium is transmitted to the lungs via seeding and inhalation was reported to be effective directly. Chronic $H$. pylori infection leads to bronchial epithelial proliferation via increased gastrin level and cyclooxygenase-2. Moreover, it contributes to pulmonary carcinogenesis. In conclusion, an association between $H$. pylori infection and pulmonary carcinoma may be revealed by variable studies, and the underlying mechanisms can be understood.

Keywords: Helicobacter pylori, etiology, lung carcinoma

\section{öz}

Amaç: Akciğer karsinomlarında mesleki ve çevresel karsinojenlere maruziyet önemli olmakla birlikte, ailevi yatkınlık, genetik anormallikler ve son olarak Helicobacter pylori infeksiyonu ilişkisi gibi bazı diğer faktörler sorgulanmaktadır. Bu çalışmada Helicobacter pylori ve akciğer karsinom ilişkisi üzerinde durulmuştur.

Yöntemler: Otuz sekiz erkek ve 10 kadından oluşan opere edilerek histolojik verifikasyonu sağlanan 48 akciğer karsinomu olgusu çalışmaya alınmıştır. Bunların 22'si skuamöz hücreli karsinom 26'sı adenokarsinomdur. Akciğer karsinomu dişı nedenlerle pulmoner operasyon geçiren 20 olgu kontrol grubunu oluşturmaktadır. Karsinom olgularında tümöre bitişik nonneoplastik parankimal ve bronşial doku örnekleri Giemsa ile boyanmıştır. Kontrol grubunda ise bronş kesiti içeren pulmoner doku örnekleri boyamaya alınmıştır. Giemsa boyalı kesitlerde bronş epiteli ve lümeninde basil aranmıştır.

Bulgular: Helicobacter pylori 48 karsinom olgusunun ikisinde saptanmıştır. Bu iki olguda histopatolojik tanı skuamöz hücreli karsinomdur. Kontrol grubunda ise basil saptanmamışır.

Sonuç: Serolojik çalışmalarla akciğer kanseri ve Helicobacter pylo$r i$ arasında ilişki ortaya konmaya çalışılmakla birlikte çelişkili sonuçlar elde edilmiştir. Ekilme ya da inhalasyon ile akciğere ulaşan bakterinin direkt olarak etkili olduğu söylenmektedir. Kronik Helicobacter pylori enfeksiyonunun gastrin ve COX-2 seviyelerini arttırarak bronş epitel proliferasyonu ve bunun ötesinde pulmoner karsinogeneze katkıda bulunduğu öne sürülmektedir. Sonuç olarak Helicobacter pylori infeksiyonu ve akciğer karsinomu arasındaki ilişki farklı tipteki çalışmalarla ortaya konabilir ve altta yatan mekanizmalar açığa çıkarılabilir.

Anahtar Kelimeler: Helicobacter pylori, etyoloji, akciğer kanseri

\section{Introduction}

Primary carcinoma of the lung is the most common cause of cancer death for both men and women and accounts for $28 \%$ of the overall cancer deaths (1). It frequently occurs in association with occupational and environmental exposure to carcinogenic agents. There are some other factors related to the development of lung cancer, such as familial predisposition, genetic alteration, and more recently, Helicobacter pylori (HP) infection (2-4).

Cite this article as: Büyükpınarbaşılı N. Helicobacter pylorias an Etiologic Factor in Primary Lung Carcinoma. Bezmialem Science 2018; 6: $134-7$.

This study had been presented as a poster announcement at XXVh National Pathology Congress in Bursa.

Araştırma XXV. Ulusal Patoloji Kongresi, 2015-Bursa'da poster bildiri olarak sunulmuştur.

Address for Correspondence/Yazışma Adresi: Nur BÜYÜKPINARBAŞILI, Bezmialem Vakıf Üniversitesi Tıp Fakültesi,

Received / Geliş Tarihi : 18.04 .2017 
Helicobacter pylori infection of the gastric mucosa affects approximately $50 \%$ of the world's population (5). A very high seroprevalence of HP has been reported worldwide, especially in developing countries (6). Overall, $70 \%-80 \%$ of the adults and $50 \%-60 \%$ of the children are seropositive for HP in Turkey $(7,8)$.

Helicobacter pylori is the main cause of chronic antral gastritis and is strongly associated with peptic ulcer disease, gastric cancer, and gastric MALT-lymphoma (9). Recently, some extradigestive disorders, including cardiovascular, skin, rheumatic, and liver diseases, have also been associated with HP infection (9). Furthermore, a number of studies have reported an association between HP infection and a variety of extradigestive disorders such as respiratory diseases. Moreover, lung cancer has been found to be 2-3 times more prevalent in peptic ulcer patients than in healthy subjects (10). These findings have suggested that HP plays a role in the pathogenesis of the lung cancer. We aimed to investigate the prevalence of HP in lung cancer cases.

Table 1. Distribution of age, gender, and pathological features of cases in patient and control groups

\begin{tabular}{l|c|c|} 
& $\begin{array}{c}\text { Patient group } \\
(n=48)\end{array}$ & $\begin{array}{c}\text { Control group } \\
(n=20)\end{array}$ \\
\hline Age range (years) & $45-84$ & $22-70$ \\
Median age (years) & 58 & 51 \\
Gender (F/M) & $10 / 38$ & $6 / 14$ \\
Smoker (+/-) & $46 / 2$ & $17 / 3$ \\
Localization of tumor & $23 / 25$ & - \\
(Central/Peripheral) & & - \\
Range of tumor size (cm) & $1.5-9$ & - \\
Tumor type (SCC/AC) & $22 / 26$ & - \\
\hline F: female; M: male; SCC: squamous cell carcinoma; AC: adenocarcinoma
\end{tabular}

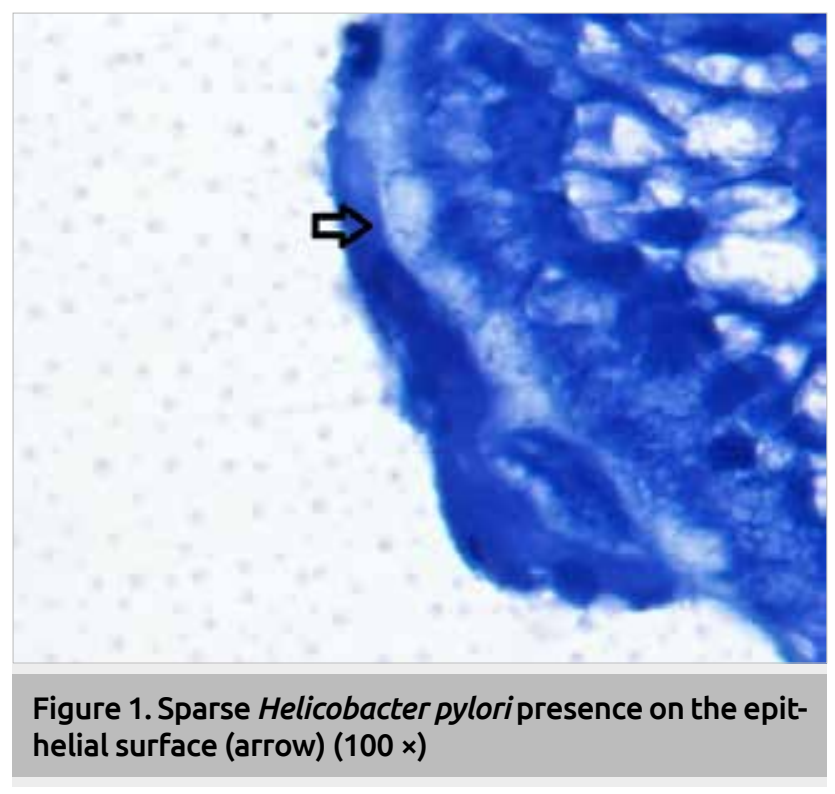

\section{Methods}

In total, 48 histologically verified lung cancer cases operated in a thoracic surgery department in January 2013-June 2015 were included in this study. The characteristics of cases are shown in Table 1 . The cases included 38 males and 10 females; 22 were squamous cell carcinoma cases and 26 were adenocarcinoma cases. The age of the patients ranged from 45 to 84 years and the median was 58 . The exclusion criteria were (1) prior Helicobacter eradication therapy, (2) consumption of acid suppressive drugs or antibiotics in the preceding 6 months, and (3) a history of operation of the upper gastrointestinal tract.

Twenty cases underwent to thoracic surgery for reasons other than lung carcinomas constituted to control group (Table 1). The reasons for surgery in the control group were bullae in 10 cases, sequel lesions in 8 cases, and pulmonary hamartomas in 2 cases. The exclusion criteria for the control group were (1) a known history of lung cancer, (2) prior Helicobacter eradication therapy, (3) consumption of acid suppressive drugs or antibiotics in the preceding 6 months, and (4) a history of operation of the upper gastrointestinal tract.

In the pulmonary carcinoma cases, both adjacent nonneoplastic parenchymal and bronchial tissue examples were stained using the Giemsa stain. The same studies were also applied to the pulmonary tissue-contained bronchial sections in the control cases. HP bacilli were examined in the bronchial epithelia and lumina in the Giemsa stained slides. Histochemical studies were applied using the automatic VentanaBenchmark Special Stain Device (Tuscon, Arizona, USA).

\section{Results}

Helicobacter pylori was found in 2 of 48 carcinoma cases (Figure 1). The ages of these cases were 52 and 54 years. Both of them were males and were smokers. These tumors were centrally localized. One tumor was $4.5 \mathrm{~cm}$ and the other was $6 \mathrm{~cm}$ in diameter. The histopathological diagnosis of these 2 cases was squamous cell carcinoma. Neither the control group nor the adenocarcinoma cases were stained for the bacillus. However, only 2 cases were positive for HP, which limits the statistical evaluation of this study.

\section{Discussion}

Helicobacter pylori is a spiral shaped gram negative bacterium. The phenotypical differences in isolated HP are either related or not to the production of vacuolated cytotoxin (VacA) and cytotoxin-related protein (CagA). Type I HP can produce these proteins. The others who are unable to produce these proteins are classified as Type II. Type I infections lead to a serious disorder (11). The International Agency for Research on Cancer classified HP as a group I carcinogenic agent (12). The upregulation of gastrin and cyclo-oxygenase-2 (COX-2), which may contribute in the angiogenesis and tumor development in HP infection, has been shown to lead to lung cancer development (4). 
Urease, a surface enzyme of HP, is involved in HP infection. The urease mRNA was found to be highly expressed in gastric cancer tissues (13). Cell proliferation rate of gastric cancer cells was found higher after stimulation with HP exudate having strong urease activity than with low urease activity (13). These results suggest that urease has an important role in the development of gastric mucosal hyperproliferation. In recent years, HP urease enzyme was found to access the lung in the gastroesophageal reflux disease; thus, $\mathrm{HP}$-associated urease may also have an important role in the proliferation and carcinogenesis of pulmonary mucosa (13).

Plasma gastrin level is high in HP infection, suggesting that this hormone contributes to the lung carcinogenesis by inducing higher proliferation of bronchial epithelium leading to the induction of COX-2 (1).

Lung cancers exhibit higher expression and content of gastrin and its receptors are akin to the upregulation of gastrin biosynthesis already described for gastric cancers and colorectal cancers (1).

Gastrin is known to be the most potent mucosal growth factor in the gastrointestinal tract and possibly also effective in the bronchial mucosa. It is assumed that this hormone has a key role in the initiation and progression of cancer both in the gastrointestinal tract and in the lungs, which have an embryologically common origin (4).

Lungs develop embryologically from the endodermal cells similar to the gastrointestinal tract and have similar cells producing several hormonal peptides (11). The increased plasma gastrin level associated with HP infection may contribute to pulmonary carcinogenesis via the introduction of the proliferation of bronchial mucosal cells (11).

Gastric mucosal colonization with HP stimulates the release of various inflammatory mediators, such as cytokines, eicosanoids, and proteins of the acute phase (14). Moreover, molecular mimicry between bacterial and host antigens exists in HP-infected patients (14). Therefore, a pathogenic link between HP infection and diseases activated by inflammatory mediators and/or induction of autoimmunity might exist. Chronic inflammation and increased immune response have been observed in a variety of respiratory diseases, including chronic bronchitis and bronchiectasis (14). Moreover, both chronic obstructive pulmonary disease and pulmonary tuberculosis are more frequent in peptic ulcer patients than in the general population (14). Based on these facts, many recent studies have focused on the potential association between HP infection and various respiratory disorders.

The relationship between HP seropositivity and lung cancer has been investigated in many studies. Ece et al. (11) found a 93\% seroprevalence of antibodies against HP in 40 consecutive patients with lung cancer and a $42 \%$ seroprevalence in 12 control subjects. The results of the study by Behroozian and Moradkhans (1) showed that the population of patients with lung cancer has a significantly higher rate of seropositivity for antibodies against HP (48 of 66) than the population of subjects without lung cancer (34 of 66; OR $=2.51,95 \%$ $\mathrm{CI}=1.14-5.54 ; \mathrm{p}<0.05)$. However, Philippou et al. (9) reported that the seropositivity for HP did not differ significantly between patients with lung cancer and controls $(61.1 \%$ vs. $55.9 \%$; $>0.05)$. Similarly, no such association was confirmed in the study by Najafizadeh et al. (10) in Iran performed on 40 patients with lung cancer, which may be due to the small sample size.

In a meta-analysis, Zhuo et al. (15) found that lung cancer risk among HP-infected individuals was 3.24-fold compared with the HP-non-infected controls.

The reason for the higher prevalence of HP infection in the lung cancer patients is not apparent. However, the majority of cancer patients were smokers (11). Furthermore, data on the relation between HP infection and smoking habits are controversial. The prevalence of HP infection in smokers has been varyingly reported as low (16), normal (17), and high (18). Besides the controversial serological results with respect to the relationship between HP and lung carcinoma, it is suggested that the bacterium (HP) reached the lung via seeding and inhalation and may have a direct effect (9). Nevertheless, a direct HP isolation has not been performed in pulmonary carcinoma specimens in these reported studies. Therefore, investigating the presence of HP directly in the pulmonary tissue has been aimed in this study.

There are obvious limitations of these published studies. First, the small sample sizes were likely inconclusive in the evaluation of the relationship between HP infection and lung cancer risk. Second, not all controls were comparable with the cases. Third, an important confounder, smoking, was not considered nor fully adjusted as a strong risk factor for lung cancer. Fourth, none of the studies explored the lung tissue $\mathrm{HP}+$ rate and the differential association with different lung tumor types (13).

The limitations of this present study are (1) lack of entirely healty individuals in the control group, (2) lack of serological evaluation aspect to HP through a retrospective study, and (3) a relatively small group for statistical evaluation.

\section{Conclusion}

An HP eradication therapy is a revolutionized concept of treatment and outcome prediction for microbial infectionrelated malignancies, specifically gastric cancers. Authors also propose the eradication of HP in lung cancer.

Therefore, we believe that further studies are needed to examine whether the association between these 2 diseases exists. If it is true, HP eradication would be a promising way in lung cancer therapy. 
Ethics Committee Approval: Ethics committee approval was received for this study from the ethics committee of Bezmialem Vakif University.

Informed Consent: Written informed consent was obtained from patients who participated in this study.

Peer-review: Externally peer-reviewed.

Conflict of Interest: No conflict of interest was declared by the author.

Financial Disclosure: The author declared that this study has received no financial support.

Etik Komite Onayı: Bu çalışma için etik komite onayı Bezmialem Vakıf Üniversitesi'nden alınmıştır.

Hasta Onamı: Yazılı hasta onamı bu çalışmaya katılan hastalardan alınmıştır.

Hakem Değerlendirmesi: Dış bağımsız.

Çıkar Çatışması: Yazar çıkar çatışması bildirmemiştir.

Finansal Destek: Yazar bu çalışma için finansal destek almadığını beyan etmiştir.

\section{References}

1. Behroozian R, Moradkhan E. The assessment of probable relationship between lung cancer and Helicobacter pylori infection. Trop Gastroenterol 2010; 31: 34-6.

2. Sellers TA, Bailey-Wilson JE, Elston RC, Wilson AF, Elston GZ, Ooi WL, et al. Evidence for Mendelian inheritance on the pathogenesis of lung cancer. J Natl Cancer Inst 1990; 82: 1272 9. [CrossRef]

3. Weinberg RA. Tumor suppressor genes. Science 1991; 254: 1138-46. [CrossRef]

4. Gocyk W, Niklinski T, Olechnowicz H, Duda A, Bielański W, Konturek PC, et al. Helicobacter pylori, gastrin and cyclooxygenase-2 in lung cancer. Med Sci Monit 2000; 6: 1085-92.

5. Mitchell H, Megraud F. Epidemiology and diagnosis of Helicobacter pylori infection. Helicobacter 2002; 7(Suppl 1): 8-16.
6. Reshetnikov OV, Denisova DV, Zavyalova LG, Haiva VM. Granberg C. Helicobacter pylori seropositivity among adolescents in Novosibirsk, Russia: prevalence and associated factors. J Pediatr Gastroenterol Nutr 2003; 36: 72-6. [CrossRef]

7. Us D, Hascelik G. Seroprevalence of Helicobacter pylori infection in an asymptomatic Turkish population. J Infect 1998; 37: 148-50. [CrossRef]

8. Yilmaz E, Dogan Y, Gurgoze MK, Unal S. Seroprevalence of Helicobacter pylori infection among children and their parents in eastern Turkey. J Paediatr Child Health 2002; 38: 183-6. [CrossRef]

9. Philippou N, Koursarakos P, Anastasakou E, Krietsepi V, Mavrea S, Roussos A, et al. Helicobacter pylori seroprevalence in patients with lung cancer. World J Gastroenterol 2004; 10: 3342-4. [CrossRef]

10. Najafizadeh K, Falah Tafti S, Shiehmorteza M, Saloor M, Jamali M. Helicobacter pylori seroprevalence in patients with lung cancer. World J Gastroenterol 2007; 13: 2349-51. [CrossRef]

11. Ece F, Hatabay N, Erdal N, Gedik C, Guney C, Aksoy F. Does Helicobacter pylori infection play a role in lung cancer? Respir Med 2005; 99: 1258-62.

12. International Agency for Research on Cancer. Schistosomes, liver flukes and Helicobacter pylori. IARC monographs on the evaluation of carcinogenic risks to humans, vol. 61. Lyon, France: IARC; 1994.

13. Deng B, Li Y, Zhang Y, Bai L, Yang P. Helicobacter pylori infection and lung cancer: a review of an emerging hypothesis. Carcinogenesis 2013; 34: 1189-95. [CrossRef]

14. Roussos A, Philippou N, Gourgoulianis KI. Helicobacter pylori infection and respiratory diseases: a review. World J Gastroenterol 2003; 9: 5-8. [CrossRef]

15. Zhuo WL, Zhu B, Xiang ZL, Zhuo XL, Cai L, Chen ZT. Assessment of the relationship between Helicobacter pylori and lung cancer: a meta-analysis. Arch Med Res 2009; 40: 406-10. [CrossRef]

16. Ogihara A, Kikuchi S, Hasegawa A, Kurosawa M, Miki K, Kaneko E, et al. Relationship between Helicobacter pylori infection and smoking and drinking habits. J Gastroenterol Hepatol 2000; 15: 271-6. [CrossRef]

17. Brenner H, Rothenbacher D, Bode G, Adler G. Relation of smoking and alcohol and coffee consumption to active Helicobacter pylori infection: cross sectional study. BMJ 1997; 315: 1489-92. [CrossRef]

18. Parasher G, Eastwood GL. Smoking and peptic ulcer in the Helicobacter pylori era. Eur J Gastroenterol Hepatol 2000; 12: 843-53. [CrossRef] 